\title{
A LIST OF THE WEST INDIAN DRYOPID $Æ$ (COLEOP- TERA), WITH A NEW GENUS AND EIGHT NEW SPECIES, INCLUDING ONE FROM COLOMBIA
}

\author{
By P. J. Darlington, JR.
}

Museum of Comparative Zoölogy, Cambridge, Mass.

Since 1927, when I published a paper on the West Indian “Helmidæ" or Helminæ (Psyche 34, pp. 91-97), a considerable amount of additional dryopid material has come to hand. Most of it has been collected by myself during a trip to Cuba, Jamaica, and Haiti which I was enabled to make from August to November, 1934, through grants from the Milton Fund and Atkins Foundation of Harvard University. This paper is to report upon this material and to bring our knowledge of the West Indian fauna up-to-date by listing the species, sometimes with critical comments. It does not pretend, however, to be a complete revision.

By the "West Indies" I do not mean to include Trinidad, which is South American both geographically and faunistically. Among the Dryopidæ, the genera Dryops, Elsianus, and Heterelmis occur in Trinidad (collected by me in 1929) but are not, at least as yet, known from the West Indies proper, and one of the Trinidad species of Helmis (s. lat.) belongs to a group not yet known from the West Indies. In my 1927 paper I stressed the relationship of the West Indian species with those of Texas. Actually, of course, many of the species show close relationship with Central America as well as Texas, and there are some South American elements in the Lesser Antilles. The West Indian fauna and that of the adjacent mainland are still so imperfectly known that there is not much point in discussing affinities in more detail, except to note that the West Indian fauna is certainly depauperate.

The absence of Dryopidæ in many rivers and brooks in the West Indies is a striking phenomenon, worth recording 
in detail. In Jamaica I looked carefully for the family in several rivers and mountain brooks on the south slope of the main range of the Blue Mountains, in the Hope River near Kingston, and in several small, clear, rapid rivers near Ocho Rios on the north coast, but did not find a single specimen, although Dryopidæ are known from the island. I visited also the Rio Cobre above Spanishtown, which looked like good dryopid water but was too flooded for collecting. In Haiti I worked carefully in the river at Ennery and the brooks on Mt. Basil (northern Haiti), in the Rivière Cul de Sac and the Rivière Froide (near Port-au-Prince), and in various mountain brooks in the high Massif de la Selle (southeastern Haiti) up to over 6,000 ft. in the Rivière Blanche on the La Selle plateau, with equally little result. However, in the La Hotte region (southwestern Haiti) I found Dryopidæ in every river and brook examined, from the Ravine du Sud at Camp Perrin, under 1,000 ft., to a small brook at Desbarrière, just north of Mt. La Hotte, at about 4,000 ft., the highest running water I saw in the La Hotte region. Five genera and eight species of stream loving Dryopidæ were found in this region. Possibly extensive clearing of forests, resulting in heavy freshets, has eliminated the insects in places by tearing up the stream beds and destroying aquatic vegetation, while they survive where, as near La Hotte, the forest is mostly uncut or where conditions are favorable for some other reason.

The proportions given in my descriptions have been determined by actual measurements. The types of all new species are in the Museum of Comparative Zoölogy. I am much indebted to Mr. K. G. Blair for notes on some types in the British Museum.

\section{Subfamily Psepheninæ \\ Psephenus Hald}

Although this genus is not known from the West Indies, an understanding of its secondary sexual characters is important in dealing with its West Indian relatives. In Psephenus lecontei Lec. the $o$ differs from the $q$ as follows: average size smaller; prothorax less explanate at sides; pronotum less opaque; elytra slightly less distinctly 
substriate; antennæ slightly longer, heavier, and more nearly serrate; maxillary palpi longer, heavier, with last joint more triangular; front and middle tarsi not dilated but with soles first 2 joints with numerous rather short, slender papillæ; middle coxæ much more approximate, mesosternum between them narrower and more acutely impressed; abdomen with 7 ventral segments (6th showing only at sides of 7 th, in emargination of apex of 5th), not 6 as in $\%$.

Pheneps n. gen.

Generally similar to Psephenus, but more slender; head free; coxæ similar; last tarsal joint elongate, but not quite so much as in Psephenus ; epipleuræ similar, nearly reaching apex of elytra; sexual dimorphism of palpi, mesosternum, and apical segments of abdomen similar. Differs from Psephenus in clypeus and labrum nearly in plane of front, not bent under head; in very long antennæ reaching to near middle of elytra at least in $\delta$, with 1st joint long, slightly bent, slightly thickened, 2nd less than $1 / 2$ as long, slightly thickened, 3rd about length of 1st, but more slender, about 4 times long as wide in $\delta$, outer joints gradually shorter, subserrate at least in $\hat{\delta}$; differs also in sides of prothorax not explanate, and in basal joint front and middle tarsi $\hat{o}$ enlarged as well as with papillæ, broadly oval, several times bulk of 2nd joint, deeply emarginate apically. Differs from Psephenops in very elongate antennæ and in $2 d$ joint o tarsi small, though with sexual papillæ as in Psephenus. The genotype is

\section{Pheneps gracilis $\mathrm{n}$. sp. ( $\mathrm{Pl}$. III, fig. 5)}

Male only. Moderately slender, depressed; dark grayish brown, mouth, bases of legs, last (sometimes) and apices of some or all other ventral abdominal segments testaceous; upper surface finely and very inconspicuously punctate, with fine, short, more or less decumbent gray pubescence, the direction of which varies on the elytra to form an irregular, variable, sericeous pattern in some lights. Head not quite $3 / 5$ width prothorax; eyes large and prominent; clypeus very wide, short, free at sides; labrum equally 
wide and short; palpi and antennæ ( $\hat{o}$ ) as described above. Prothorax transverse, about $2 / 3$ wider than long, moderately narrowed anteriorly, apex about $3 / 5$ width of base; sides more or less unevenly arcuate, nearly parallel basally, not margined, not explanate; base lobed before scutellum, broadly emarginate at sides; apex slightly arcuate anteriorly; basal angles acute posteriorly but not much produced, apical angles rounded-obtuse; disk more or less evenly convex, with faint longitudinal impressed line at middle near base. Elytra ample, together $3 / 10$ wider than prothorax, sides slightly diverging in basal $1 / 2$, broadly rounded to the independently rounded apices; surface with faint, irregular longitudnal impressions or striæ. Abdomen below with 2 basal segments deeply emarginate at middle, 1st entirely hidden by coxæ medially. Mesosternum and $\hat{\delta}$ tarsi as described above. Length 4 or slightly more; width 2 or slightly more $\mathrm{mm}$.

Haiti: holotype of (M. C. Z. no. 21,785) and 5 o paratypes ( 1 in U. S. N. M.) from Tardieu, in the valley just north of Mt. La Hotte (Pic de Macaya), about 3,000 ft., Oct. 14, 1934, taken with a light at night in depressions on stones in the turbulent Rivière Tardieu. The insects were a foot or so above water level on stones which were dry but entirely surrounded by water. They were apparently resting, but ran actively when disturbed. The $q$ characters of the genus have been taken from the following species:

\section{Pheneps cubanus n. sp. (Pl. III, fig. 6)}

Female only. Moderately slender, depressed; testaceous brown, paler below; upper surface dull and finely and densely roughened on pronotum, less so on elytra, not distinctly punctate; pubescence fine, short, subdecumbent, mixed with some slightly longer hairs, not forming sericeous patterns in any light. Head about $3 / 5$ width prothorax; eyes large and prominent; front slightly concave at sides, faintly convex at middle; clypeus very wide and short, free at ends; labrum distinctly narrower; antennæ (last 5 joints missing) slightly finer and with slightly shorter joints than in gracilis; maxillary palpi shorter, finer, and with more oval apical joint. Prothorax transverse, about twice as wide 
as long, strongly narrowed anteriorly from the acute basal angles; sides not margined, not explanate, slightly arcuate basally, more so anteriorly where rounded into front margin; latter arcuate, almost lobed, at middle; base lobed before scutellum, broadly emarginate at sides; disk rather irregularly convex but without distinct impressions. Elytra ample, together $1 / 3$ wider than prothorax, formed as in gracilis but surface even less distinctly impressed. Abdomen ( $q$ ) with 6 ventral segments, 1st and 2nd not emarginate at middle. Mesosternum ( $q$ ) broader and less acutely impressed between middle coxæ than in gracilis ( $\hat{o})$. Front and middle tarsi ( $q$ ) slender, about as in Psephenus, without sexual papillæ. Length not quite 4; width not quite $2 \mathrm{~mm}$.

Cuba: holotype o (M. C. Z. no. 21,786) unique from Soledad, near Cienfuegos, Santa Clara, Nov. 2, 1926, taken by myself. I do not remember the circumstances of capture.

Of the numerous characters which distinguish this species from gracilis as described, the different form of the prothorax (not subparallel near base in cubanus) and the different color and more regular pubescence may be presumed to be specific characters. The more densely roughened pronotum, narrower labrum, and entire 1st and 2nd ventral segments of cubanus may prove to be either specific or sexual differences, probably the latter. The shorter, slightly differently formed antennæ and palpi, the fewer ventral segments, more widely separated middle coxæ, and much smaller basal joint of front and middle tarsi, without papillæ, are, by analogy with Psephenus, strictly sexual characters and are so treated in my generic description of Pheneps.

\section{Psephenops Grouvelle}

\section{(Xexanchorinus Grouvelle)}

Notes from the Leyden Museum 20, 1898, pp. $44 \& 45$.

The gentoype of Psephenops is P. smithi Grouv. All of the types of this species were $\hat{o}$ o . Champion (Trans. Ent. Soc. London 1913, p. 63, Pl. 3, figs. $2 \& 2$ a) believed he had a $q$ Psephenops with dilated tarsi and 6 ventral segments. However, Mr. K. G. Blair has kindly examined 
Champion's specimen for me and writes that he thinks it is undoubtedly a $\hat{\delta}$, with apical abdominal segments and mesosternum between the coxæ formed as in $\hat{\delta} \hat{o}$ of allied genera. Actually the $q$ of Psephenops, as shown by my $P$. haitianus (below), has slender tarsi and differs from the o rather strikingly in its larger size and differently formed prothorax. It happens that there is an insect, Xexanchorinus latus Grouv., described from the exact locality of one of the types of Psephenops smithi, which differs from the latter about as my o Psephenops haitianus differs from the i. Mr. Blair has compared Xexanchorinus latus with Psephenops smithi (types of both in British Museum) and writes that the antennæ of the two are similarly constructed and the elytral sculpture much the same. Judging from the sketches in Mr. Blair's letter, the dimorphism of the prothorax is about as great as in the Haitian species, and I am convinced that Psephenops smithi is the $\hat{0}$ and Xexanchorinus latus the $o$ of one species. The former name has page priority as to both genus and species.

In accordance with these conclusions, and taking into account the peculiar heteromerous structure of the $\hat{\delta}$ tarsi in $P$. haitianus, the secondary sexual characters of Psephenops are these: of smaller and narrower than $\&$, with narrower and more rounded prothorax which is less explanate at the sides; mesosternum between middle coxæ very narrow in $\hat{o}$, much broader in $q$; $\hat{o}$ with 7 , $q$ with 6 ventral segments conformed as usual in Psepheninæ; dimorphism of antennæ and palpi less than usual in subfamily; $\hat{o}$ with first and second joints front and middle tarsi and either first and second or only first joint of hind tarsus dilated and conspicuously lobed below, with densely pubescent soles; $\&$ with slender and simple tarsi. It will be noted that all of these secondary sexual characters are either foreshadowed or duplicated in Psephenus or Pheneps or both, and that sexual dimorphism of the prothorax occurs also in some species of Phanocerus.

3. Psephenops smithi Grouvelle ô

(Xexanchorinus latus Grouvelle ( $q)$ )

L. c., pp. $45 \& 46$.

Grenada and St. Vincent. The type locality of X. latus is 
Chantilly Estate (windward side), Grenada, whence came at least one of the types of $P$. smithi. Mr. Blair writes that the hind tarsus of the $\hat{o}$ has two dilated and lobed joints, like the front and middle tarsi.

Psephenops maculicollis n. sp. (Pl. III, fig. 1)

Not West Indian, but described here because it is the only typical Psephenops I myself have had for comparison with the new West Indian species.

Male only. Psephenus-like, rather depressed; brown, head black; pronotum dull reddish testaceous, dusky across base, with large, round, shining, piceous mark at middle from apex to about $2 / 5$ from base and extending in a fine line on carina nearly to base; each elytron with a short testaceous fascia from near humerus obliquely back and inward; dorsal surface with fine, short, close pubescence, relatively sparse on pronotum; head, middle of pronotum, and elytra especially near base, decreasingly distinctly, finely, and closely punctate; lower surface dark gray, appendages brown. Head about $4 / 7$ width prothorax; eyes prominent; front transversely ridged between upper parts of eyes; clypeus broad and short; labrum much narrower; antennæ short, reaching to about basal angles of prothorax, 2 basal joints somewhat enlarged, 2nd slightly shorter than 1st or 3rd, outer joints progressively shorter to subapical (wider than long), apical slightly longer. Prothorax not quite $13 / 4$ times wide as long, much narrowed anteriorly ; sides straight anteriorly, strongly rounded before basal angles; latter right; anterior angles very obtusely rounded; base lobed at middle and emarginate at sides ; apex slightly arcuate; lateral margins explanate basally; disk convex, slightly impressed near basal angles and each side near base in areas equidistant from each other and sides, strongly carinate at middle in basal 1/3. Elytra together about 3/10 wider than prothorax, somewhat shorter than abdomen, broadly, independently rounded apically; surface with usual indistinct stria-like impressions. Palpi, mesosternum, and apical segments of abdomen (dissected) as usual in $\hat{\delta}$ Psepheninæ; 1st ventral slightly emarginate at middle; all 
tarsi with 1st and especially 2nd joints elongate, lobed, and with hairy soles. Length $21 / 2$; width $11 / 3 \mathrm{~mm}$.

Colombia: holotype of (M. C. Z. no. 21,788) unique from Rio Frio, about 20 mi. south of Santa Marta, Prov. of Magdalena, Feb. 25, 1928, taken on a stone in the Rio Frio River.

Differs from Psephenops smithi Grouvelle and Ps. grouvellei Champion (l. c.) in color and in having the sides of the prothorax strongly rounded near the base. The posterior tarsi are like those of grouvellei as figured by Champion.

4. Psephenops haitianus n. sp. (Pl. III, figs. 2 \& 3)

Psephenus-like, rather depressed; dark brown, bases of legs, parts of lower surface, and base of elytra pale, pale area extending back (vaguely) on each elytron in a triangle $1 / 3$ of length; upper surface roughened, especially on pronotum of $q$, not distinctly punctate, with fine, short, uniform, subdecumbent pubescence. Head small, just over 1/2 ( $\hat{o}$ ) or less than $1 / 2$ ( $q$ ) width prothorax; eyes prominent; front faintly concave; clypeus wide, short, free at ends; labrun narrower; antennæ moderate, reaching well ( $\hat{o}$ ) or slightly ( $q$ ) beyond basal angles of prothorax, first 2 joints rather stout, 2nd about 1/2 length 1st, 3rd 1/2 longer than 2nd, outer joints progressively slightly shorter. Prothorax transverse, over 2 ( $\hat{o}$ ) to about 21/2 ( $q$ ) times wide as long; much narrowed anteriorly; sides not margined, not explanate, slightly and evenly arcuate ( $\hat{o}$ ) or sinuate before the posterior angles ( $q$ ) ; latter acute; anterior angles very obtuse; base broadly lobed before scutellum, emarginate at sides; apex nearly truncate; disk convex, faintly depressed before posterior angles, very obsoletely carinate at middle of base. Elytra ample, together about 1/3 ( $\hat{o}$ ) to $1 / 2$ ( $q$ ) wider than prothorax; sides nearly straight and slightly divergent basally, broadly rounded to the independently rounded apices; surface with faint, longitudinal, stria-like impressions, more distinct in $\%$, in which alternate intervals are slightly elevated near suture. Length ( $\left.\begin{array}{ll}\hat{o} & q\end{array}\right)$ about $21 / 2$ $\& 31 / 2$; width $12 / 5 \& 21 / 10 \mathrm{~mm}$. (exact measurement difficult because of position of specimens). 
In addition to the differences in size, proportion, and sculpture, there are the following secondary sexual characters: antennæ and palpi relatively a little more elongate in $\hat{\delta}$, but not much modified otherwise; prothorax sexually dimorphic in form, also more rounded dorso-ventrally at sides in $\hat{o}$, more angulate in $\circ$, especially anteriorly; mesosternum very compressed between coxæ in $\delta$, much less in o ; abdomen with 7 ventrals in o , 6 (apical visible only by dissection) in $\&$; first ventral rather strongly emarginate at middle in $\hat{o}$, much less in $\%$; $\hat{o}$ with first and second joints front and middle tarsi but only first of hind tarsus dilated, lobed below at apex, and with pubescent soles; $q$ tarsi slender, as in Psephenus.

Haiti: holotype ô (M. C. Z. no. 21,787) from Tardieu, just north of Mt. La Hotte, about 3,000 ft., Oct. 14, 1934, taken at night on a stone in the river with Pheneps gracilis; allotype + from a small brook a few miles northeast of Mt. La Hotte, about 3,000 ft., Oct. 12, taken by holding a net in the current below a leafy sappling which had fallen into the brook and which I combed out thoroughly. In spite of the differences between these specimens there are so many points of exact correspondence - in details of the pale mark on the elytra, for instance, and in the faint sub-basal carina of the prothorax - that I feel certain they are one species.

The form of the $\hat{o}$ hind tarsus distinguishes this species from all other known Psephenops. Possibly the difference may eventually prove to be of generic value.

\section{Subfamily Dryopinæ}

\section{Hexanchorus caraibus (Coquerel)}

Rev. Mag. Zoöl. (ser. 2) 3, 1851, p. 601, Pl. 15, fig. 14 (Potamophilus).

Described from Martinique and Guadeloupe.

\section{Phanocerus congener Grouvelle}

Notes from Leyden Museum 20, 1898, p. 46.

Grenada: described from Balthazar (windward side). This species should be compared with P. clavicornis Shp. of Central and South America. 


\section{Phanocerus hubbardi Schaeffer}

Journ. New York Ent. Soc. 19, 1911, p. 119.

Jamaica and Haiti: described from the former without more definite locality. I have before me one $\hat{o}$ topotype (same data as type) borrowed from the United States National Museum and $12 \hat{o}, 11$ \& from the northeastern foothills of the Massif de la Hotte, Haiti, 2-4,000 ft., Oct. $10-24,1934$, taken on water weeds, stones, and $\operatorname{logs}$ at water level in various rivers and brooks. These specimens are much darker than the Jamaican one, perhaps because of their greater freshness, and have the elytra slightly more strongly punctate. They are not so punctate as in Ph. clavicornis Sharp from Devil's River, Texas ( $\hat{\alpha} \&$ ㅇ det. Schaeffer, borrowed from U. S. N. M.), however. The females in the Haitian series have the prothorax slightly more elongate, with sides more sinuate, than the males, so that I had separated the sexes even before examining the genitalia. A somewhat similar sexual difference exists in clavicornis, but not in the following species. The $\hat{s}$ genitalia of all these species seem to be indistinguishable.

8. Phanocerus helmoides n. sp. (PI. III, fig. 4)

Subparallel, rather elongate, convex; piceous brown, with fine, short, close pubescence; appendages brown, tibiæ, tarsi, and antennal club darker. Head $2 / 3$ width prothorax. Prothorax subquadrate, $1 / 4$ (more or less) wider than long, only slightly more narrowed in front than behind; sides slightly or moderately arcuate, straight or slightly sinuate before base and apex; posterior angles right, anterior slightly obtuse but moderately prominent; explanate side margins conspicuous in anterior $1 / 3$; apex arcuate; base strongly, sinuately lobed before scutellum; disk convex, with fine median longitudinal line, fine puncture each side of middle before base, rather fine groove each side from base 1/6 from side forward and then outward to just behind apical angle. Elytra slightly wider than prothorax, strial punctures rather fine, especially apically, more as in hubbardi than clavicornis. Length $2.3-2.8$ by $1.1-1.2 \mathrm{~mm}$.

Haiti: holotype of (M. C. Z. no. 21,789) and $6 \hat{\circ}, 6$ o paratypes (pair in U. S. N. M.) from the northeastern 
foothills of the Massif de la Hotte, southwestern peninsula, 2-4,000 ft., Oct. 10-24, 1934, taken in the same situations as the preceding.

The relatively weak convolutions of the prothorax differentiate this from clavicornis, hubbardi, and congener, and give it a slightly Helmis-like aspect.

9. Lutrochus geniculatus Chev.

Ann. Soc. Ent. France (ser. 4) 4, 1864, p. 406 (Lutochrus) ; Grouvelle, Bull., Soc. Ent. France 1896, p. 17.

Cuba and Haiti: described from the former without more definite locality. I have before me a specimen (over $4 \mathrm{~mm}$. long) supposed to be from Cuba and one $(31 / 2 \mathrm{~mm}$.) from the northeastern foothills of the Massif de la Hotte, Haiti, about 3,000 ft., Oct. 12, 1929. These specimens differ from luteus Lec. of the United States just as described in Grouvelle's key $(l . c$.$) . The Haitian specimen was secured from$ the same fallen sappling which yielded the allotype of Psephenops haitianus. Another specimen was seen at the crossing of the auto road and Rivière Glace a few miles away, but flew from the edge of my net before I could reach it.

\section{Throscinus schwarzii Schaeffer}

Journ., New York Ent. Soc. 12, 1904, p. 204.

Jamaica (and Texas): described from the latter, from Brownsville. I have specimens from Brazoria Co., Texas, and one from Kingston, Jamaica, Aug. 27-29, 1934, taken in vegetation in the edge of a small pond. The Kingston specimen is not quite so roughened above as the Texan ones, but agrees well otherwise.

11. Throscinus æthiops n. sp. (Pl. III, fig. 7)

Elongate oval, convex; rather shining black above, lower surface and appendages reddish except antennal club black; pubescence moderate, longer than in schwarzi, tending to mat as in crotchi Lec. Head with front pubescent, not very closely punctate, somewhat shining (when pubescence removed); antennæ with club 7-jointed ( $i$. $e$. 5th joint stouter than 4 th and distinctly triangular), 3rd joint somewhat longer than 4 th. Prothorax just over $1 / 2$ wider than long, much narrowed anteriorly practically from the base; 
sides slightly, almost evenly arcuate; base and apex as usual; disk very convex, not distinctly impressed, inconspicuously punctate. Scutellum not distinctly punctate. Elytra about 1/8 wider than prothorax; sides subparallel basally, broadly rounded posteriorly to near apex, where strongly sinuate (as usual); disk relatively closely and coarsely punctate, secondary punctation very fine, scarcely detectable; surface rather shining. Lower surface dull and pubescent (as usual). Length between $21 / 5 \& 21 / 4$; width $1 \mathrm{~mm}$.

Haiti: holotype (M. C. Z. no. 21,790) from Trou Caiman (a large fresh lake in the Cul-de-Sac about $25 \mathrm{~km}$. northeast of Port-au-Prince), Nov. 15-20, 1934, in floating aquatic vegetation; 2 paratypes from vicinity Port-au-Prince, further data accidentally omitted.

As compared with $T$. schwarzi, xthiops is much more shining, with coarser primary and much finer and less obvious secondary elytral punctuation and longer and more matted pubescence. The antennæ are similar, with 7-jointed clubs, which distinguish the species from crotchi Lec. (type seen) and politus Casey (paratype seen, borrowed from the U. S. N. M.) of the United States, which have 6-jointed antennal clubs.

\section{Pelonomus Er.}

The following material constitutes an informal revision of all the species of this genus found north of South America.

\section{Pelonomus obscurus obscurus Lec.}

Proc. Acad. Philadelphia 6, 1852, p. 42; Horn, Trans. American Ent. Soc. 3, 1870, p. 31; Sharp, Biologia Cent.-Amer. 1, part 2, 1882, p. 122.

Not Antillean (Texas and probably neighboring regions) : Leconte's types (examined by me) are from the "southern and western states." All are o \& without more definite locality. They belong to the Texan form, of which we possess also $10 \hat{0}, 10 \%$ labeled "Tex." This typical form is characterized by a relatively broad (but somewhat variable) prosternal fissure behind the eye and by having the claw joint of the $o$ front tarsus very broad, widest near the base. 
12. Pelonomus obscurus gracilipes Chev. (Pl. III, fig. 10) (rufescens Casey)

Ann. Soc. Ent. France (ser. 4) 4, 1864, p. 406; Casey, Coleop, Notices 5, 1894, p. 581.

Cuba (and Florida) : Chevrolat's type was from the former; Casey's, from the latter. We have specimens from Soledad, near Cienfuegos, Santa Clara, Cuba, Aug., Oct., and Nov., and from Florida (Brighton near Lake Okeechobee, and Homestead) ; the species occurs in aquatic vegetation in ponds and is sometimes very abundant at light. The subspecies gracilipes differs from typical obscurus only in the usually narrower prosternal fissure and more slender anterior of claw joint, which is parallel or slightly narrowed basally. Some of my Florida specimens are strongly rufescent like Casey's types, but the majority, and all the Cuban ones, are colored like typical obscurus. There is some variation in the form of the scutellum.

Pelonomus obscurus, both subspecies, has striking secondary sexual characters, some of which were noted by Sharp $(l . c$.$) . The last 2$ joints $t$ maxillary palpi are very elongate, the subapical a little over $1 / 2$ as long as the apical (in o shorter, with relatively shorter subapical) ; the claw joint of front tarsus is broader than in the $q$; the $\delta$ middle tibiæ are bent in at apex; and $\hat{o}$ 3rd and 4 th ventral segments are shortened or telescoped so that apical segment is relatively large and usually bent down. These characters are absent in the other Pelonomus known to me, and make recognition of obscurus easy. Moreover the $\hat{o}$ genitalia of the latter are unique in that the lateral lobes are notched inwardly to receive the apex of the middle lobe.

$P$. obscurus is, of course, recorded from Mexico and Guatemala (Sharp, $l$. c.) as well as from the regions given above, but I do not know which subspecies is in Central America.

13. Pelonomus picipes (Oliv.) (Pl. III, fig. 11) (palpalis Sharp)

Ent. 3, 1795, 41 bis, p. 4, Pl. 1, fig. 2 a, b, c (Dryops); Latreille, Hist. Nat. 9, 1804, p. 226; Lacordaire, Gen. Coleop., 1855, Atl. Pl. 24, fig. 1; Coquerel, Rev. Mag. Zoöl. (2) 3, 1851, p. 602 ; Sharp, Biologia Cent.-Amer1, part 2, pp. 122 (1882) \& 774 (1887). 
Guadeloupe (and Panama): described by Olivier from the former; Sharp's types were from the latter. I have before me a single $\hat{o}$ from Gourbeyre, Guadeloupe, borrowed from the American Museum, which agrees well enough with the original description and figure and with Lacordaire's figure, and also 4 (both sexes) from Vulcan de Chiriqui, Panama, from Biologia material.

This species is very similar to obscurus, but lacks the secondary sexual characters of that species and has relatively longer posterior tarsi, about as long as the tibiæ. The lateral lobes of the $\hat{\sigma}$ genitalia are not notched. Sharp's species cannot be separated either by external or genitalic characters.

\section{Pelonomus insularis Grouv.}

Notes from the Leyden Museum 18, 1896, p. 33.

Hispaniola: described from both Santo Domingo and Haiti. I found specimens in Haiti at Etang Lachaux, southwestern peninsula, under 1,000 ft.; Poste Terre Rouge, north of the Cul-de-Sac, 2,000 ft.; Mt. Trou d'Eau, near by, $4,000 \mathrm{ft}$.; swamps north of Dessalines, near sea level; Ennery, 1,000 ft.; all Sept. to Nov., 1934; and we have 2 specimens from Diquini, near Port-au-Prince, W. M. Mann. The species occurs in aquatic vegetation and waterlogged trash in ponds or slow streams, not in rapid water.

Readily known by the very coarse punctuation of prothorax and elytra and by the traces of submarginal channels of the prothorax. The of genitalia are as in picipes.

\section{Subfamily Helminæ}

All known West Indian Helminæ belong to Helmis as Sharp and Grouvelle understood the genus ${ }^{1}$. Moreover, the West Indian species are relatively few and are evidently derived from few sources.

\section{Helmis simplex Darl.}

Psyche 34, 1927, p. 96

Cuba: described from Soledad, near Cienfuegos, Santa Clara. Additional specimens were taken in August, 1934.

${ }^{1}$ Musgrave, Proc. Ent. Soc. Washington 37, 1935, pp. 32-, has referred one West Indian species to Cyllœpus and has described a new genus for another. 
16a. Helmis cæsa minima Darl.

Psyche 34, 1927, pp. 93 \& 97; Musgrave, l. c., p. 34 (Neoelmis)

Cuba, Jamaica, and Haiti: described from Soledad, near Cienfuegos, Cuba, where retaken in August, 1934. Occurs also in Jamaica (no definite locality) and Haiti, where I found it only in the southwestern peninsula, in the La Hotte region, in rivers and brooks from 1,000 to $4,000 \mathrm{ft}$., Oct. 10-24, 1934.

I think that the various geographical forms related to Helmis cærsa Lec. (cf. Musgrave, l. c.) are best considered as subspecies. I do not mean by this to question their validity, but to show their evident relationship as slightly modified forms of one original stock.

16b. Helmis cæsa gracilis (Musgrave)

L. c., p. 35 (Neoelmis).

Puerto Rico: described from Rio Cañas, Las Marias. We possess 2 paratypes, thanks to the generosity of Mr. Musgrave.

\section{Helmis filiformis Darl. (jamaicensis Darl.)}

Psyche 34, 1927, pp. $94 \& 97$

Cuba and Jamaica: described from Soledad, near Cienfuegos, Cuba, and retaken in numbers in August, 1934. This larger series varies enough to show that the Jamaican form is probably synonymous.

\section{Helmis smithi Grouv.}

Notes fr. Leyden Mus. 20, 1898, p. 47; Darlington, Psyche 34,1927, p. 96.

Grenada (and Trinidad): described from the former (Mount Gay Estate, leeward side). In addition to a specimen from Grenada received from the U. S. N. M., I have a good series from St. Augustine, Trinidad, April, 1929, taken by myself. 


\section{Helmis danforthi (Musgrave)}

\section{L. c., p. 33 (Cyllœpus)}

Puerto Rico: described from Rio Cañas, Las Marias; there are 2 paratypes in the M. C. Z., received from Mr. Musgrave.

\section{Helmis haitiana n. sp. (Pl. III, fig. 8)}

Form average, parallel; dull black, lower surface and appendages brown, antennæ paler basally; pubescence very inconspicuous. Head dull, granular. Prothorax subquadrate, moderately narrowed in front, scarcely so behind, $1 / 5$ or $1 / 6$ wider than long; sides broadly and more or less evenly arcuate, margins faintly crenate; disk convex, with entire sinuate carinæ nearly paralleling sides, these carinæ well defined inwardly, not defined (continuous with disk) externally; median longitudinal groove obsolete anteriorly, faint at middle, defined by a pair of faint carinæ at base; surface of disk dull but not distinctly granular, finely and not very closely punctate. Elytra $1 / 4$ or $1 / 5$ wider than prothorax; sides nearly parallel basally, broadly rounded near apex; apices not produced; each elytron with 2 moderate costæ externally, evanescent on declivity; 4th interval faintly raised on disk, with a row of minute shining granules each side; 3rd interval faintly more prominent at base than 2nd or 4th; 4 discal striæ fine but distinct, indistinctly punctate; surface of disk dull but without distinct granules except on 4th interval and less distinctly on costæ (rarely a few on base of 3rd interval). Lower surface with scattered granules less obvious than usual; prosternal process about $1 / 2$ width of mesosternum between middle coxæ; prosternum carinate before front coxæ; abdomen nearly uniformly granular-alutaceous, not obviously silky; 1st ventral not longitudinally carinate behind coxæ. Length $21 / 6$ $22 / 5$; width $1 \mathrm{~mm}$.

Haiti: holotype (M. C. Z. no. 21,793) and 17 paratypes (1 in U. S. N. M.) from the northeastern foothills of the Massif de la Hotte, southwestern peninsula, 2-4,000 ft., Oct. 10-24, 1934.

Differs from danforthi not only in larger size, but in less 
granulate, more distinctly punctate pronotum, less distinctly sulcate at middle, and usually in lacking distinct shining granules on base of elytra inside 3rd stria [in danforthi there are such granules in increasing numbers on the bases of the 1st (few), 2nd, and (much more conspicuous) 3rd intervals.]

\section{Helmis quadrata Darl.}

Psyche 34, 1927, p. 95.

Cuba: described from Soledad, near Cienfuegos, where it was retaken in August, 1934.

\section{Helmis lahottensis n. sp. (Pl. III, fig. 9)}

Form about average, subparallel, but distinctly more gibbous than usual; dull black, appendages (except tarsi and bases of antennæ) not much paler; pubescence inconspicuous. Head dull, granular. Prothorax moderately narrowed anteriorly, slightly posteriorly, $1 / 5$ or $1 / 6$ wider than long; sides either evenly and slightly arcuate or subangulate at basal $2 / 5$, slightly or not sinuate before basal angles; margins crenate; disk convex, with strong, entire carinæ paralleling side margins, said carinæ defined both inwardly and (less distinctly) externally; median sulcus obsolete anteriorily, very deep at middle, sides of sulcus elevated and continued to base where fused to form single strong carina impressed along crest; surface of disk dull, finely granular, not distinctly punctate. Elytra about 1/4, wider than prothorax; sides slightly arcuate anteriorly, more posteriorly; apices not produced; each elytron with 2 moderate carinæ externally, evanescent on declivity; 3rd interval prominent basally; 4 discal striæ slightly impressed, finely and not closely punctate; intervals slightly irregular; some inconspicuous shining granules at base especially on 3rd and 4th intervals. Lower surface with small scattered granules; prosternum not distinctly carinate before coxæ; prosternal process about $1 / 2$ width mesosternum between middle coxæ; abdomen evenly granular-alutaceous, not distinctly silky, basal segment not carinate behind coxæ. Length 21/4 (more or less) ; width $1 \mathrm{~mm}$.

Haiti: holotype (M. C. Z. no. 21,794) and 10 paratypes 
(1 in U. S. N. M.) from the northeastern foothills of the Massif de la Hotte, 2-4,000 ft., Oct. 10-24, 1934. Like all the other West Indian Helmis I have taken, this is found in stony and especially gravelly places in swiftly running brooks and rivers.

Differs from quadrata and its allies in being black, with coarser sculpture and differently carinate base of pronotum.

\section{Explanation of Plate III}

(All figures from camera-lucida outlines)

1. Psephenops maculicollis n. sp. ( $\hat{o}$, holotype) $\times$ about 17 .

2. Psephenops haitianus n. sp. ( $\hat{\delta}$, holotype) $\times$ about 17 .

3. Psephenops haitianus ( + , allotype) $\times$ about 17.

4. Phanocerus helmoides n. sp. ( 9 , paratype) $\times$ about 17 .

5. Pheneps gracilis n. gen. \& sp. ( $\hat{\sigma}$, paratype) $\times$ about 9 .

6. Pheneps cubanus n. sp. ( 9 , holotype) $\times$ about 9 .

7. Throscinus athiops n. sp. (antenna of paratype).

8. Helmis haitiana n. sp. (paratype) $\times$ about 17 .

9. Helmis lahottensis n. sp. (paratype) $\times$ about 17 .

10. Pelonomus obscurus gracilipes Chev. (genitalia of $\hat{o}$ from Soledad, near Cienfugos, Cuba).

11. Pelonomus picipes (Oliv.) (genitalia of $\hat{o}$ from Gourbeyre, Guadeloupe). 
Psyche, 1936
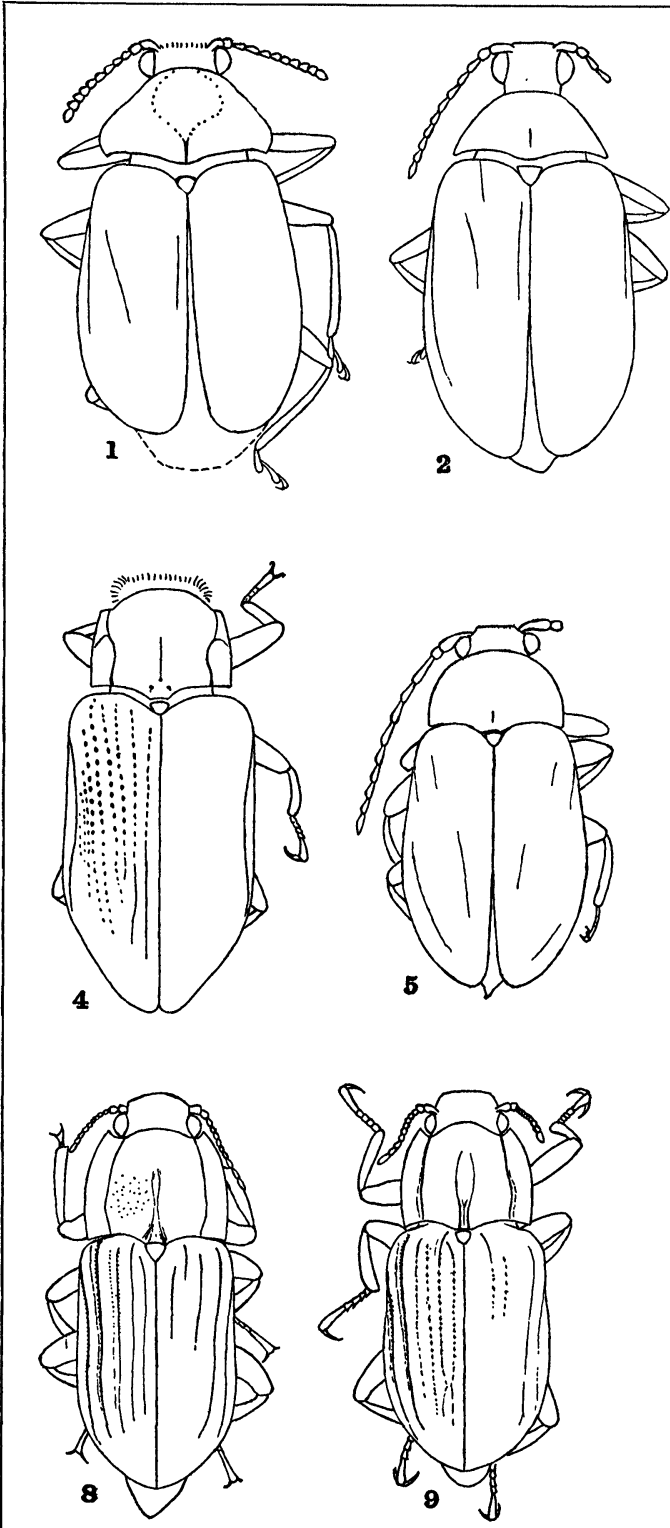

Vol. 43, Plate III.
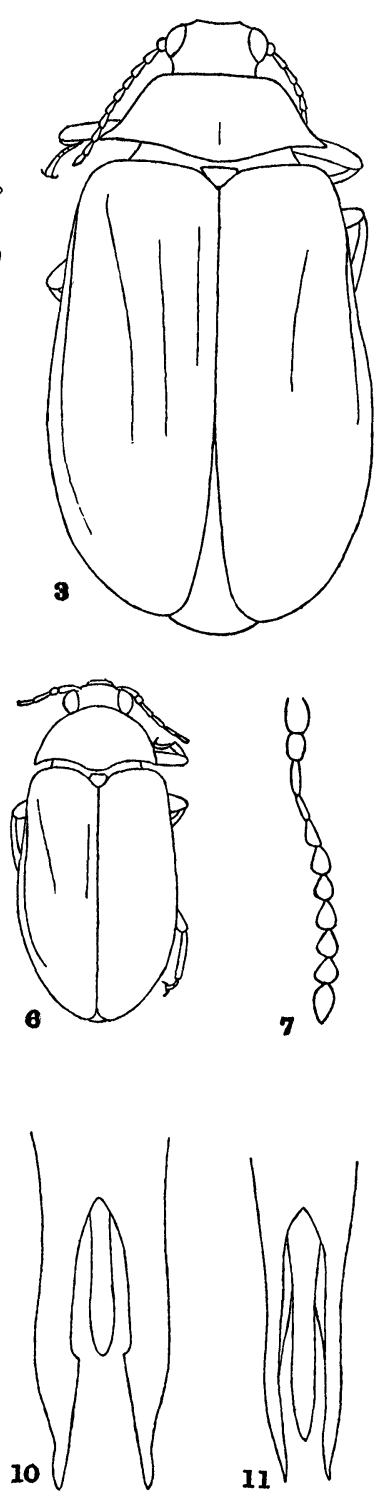

Darlington - West Indian Dryopidæ. 

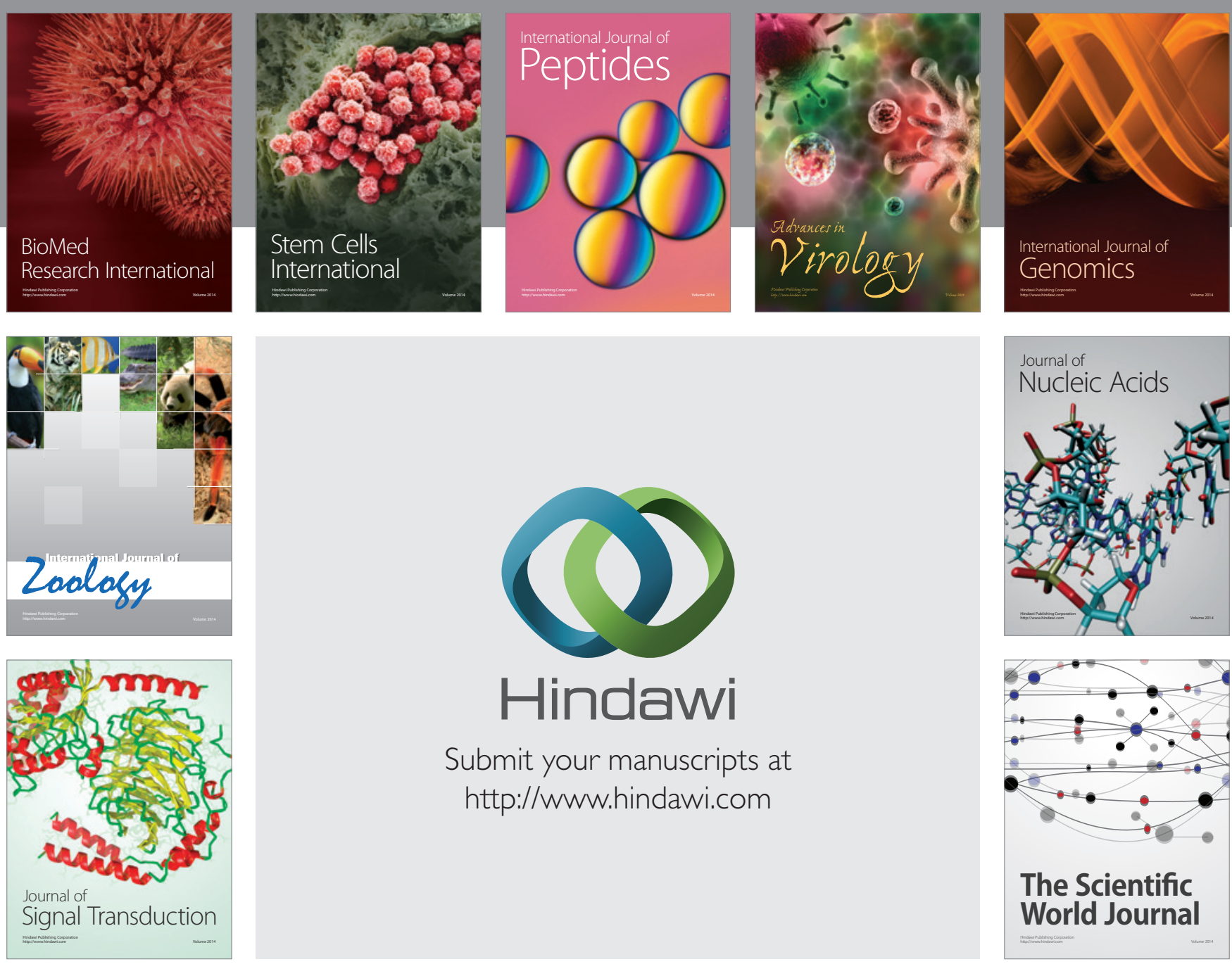

Submit your manuscripts at

http://www.hindawi.com
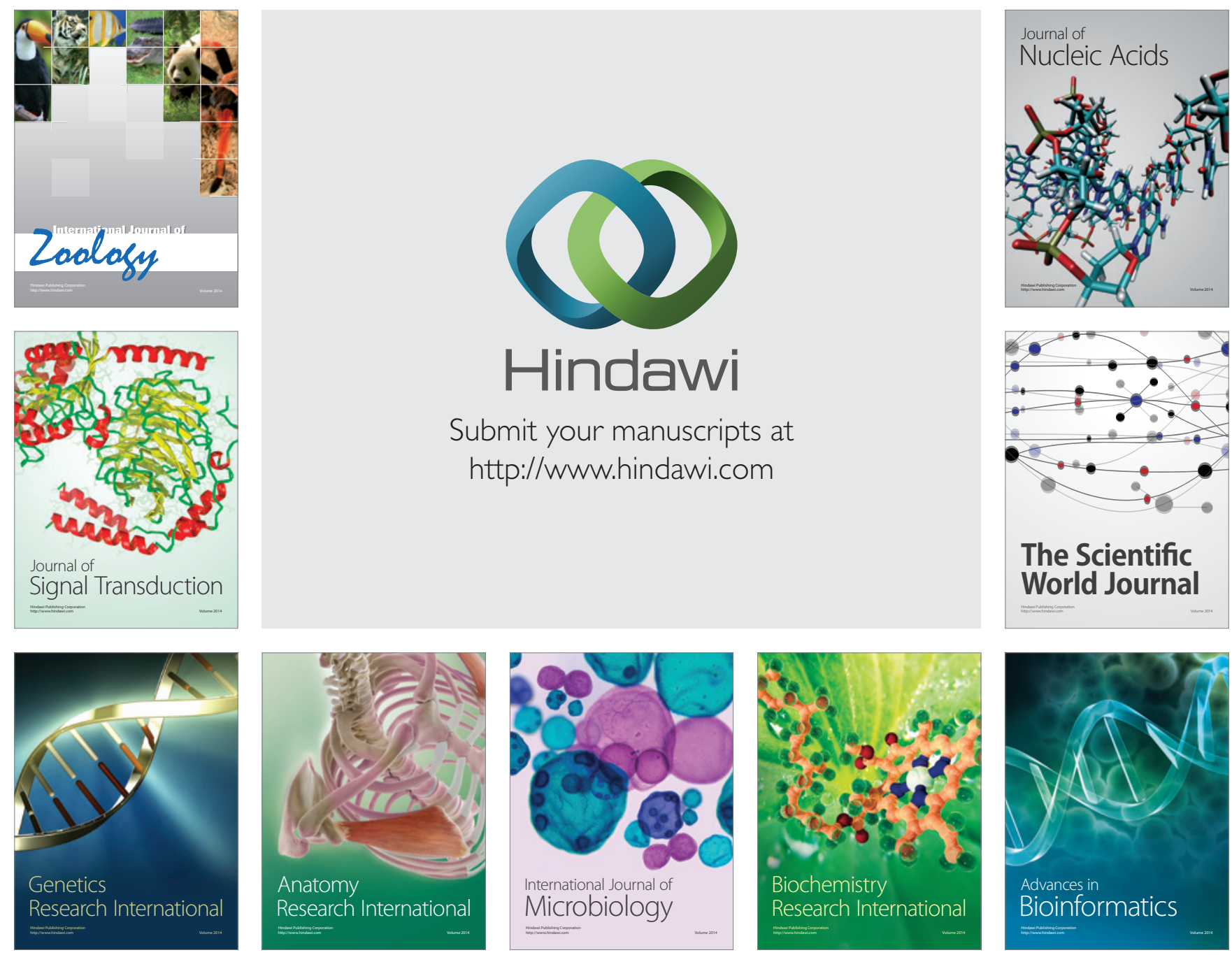

The Scientific World Journal
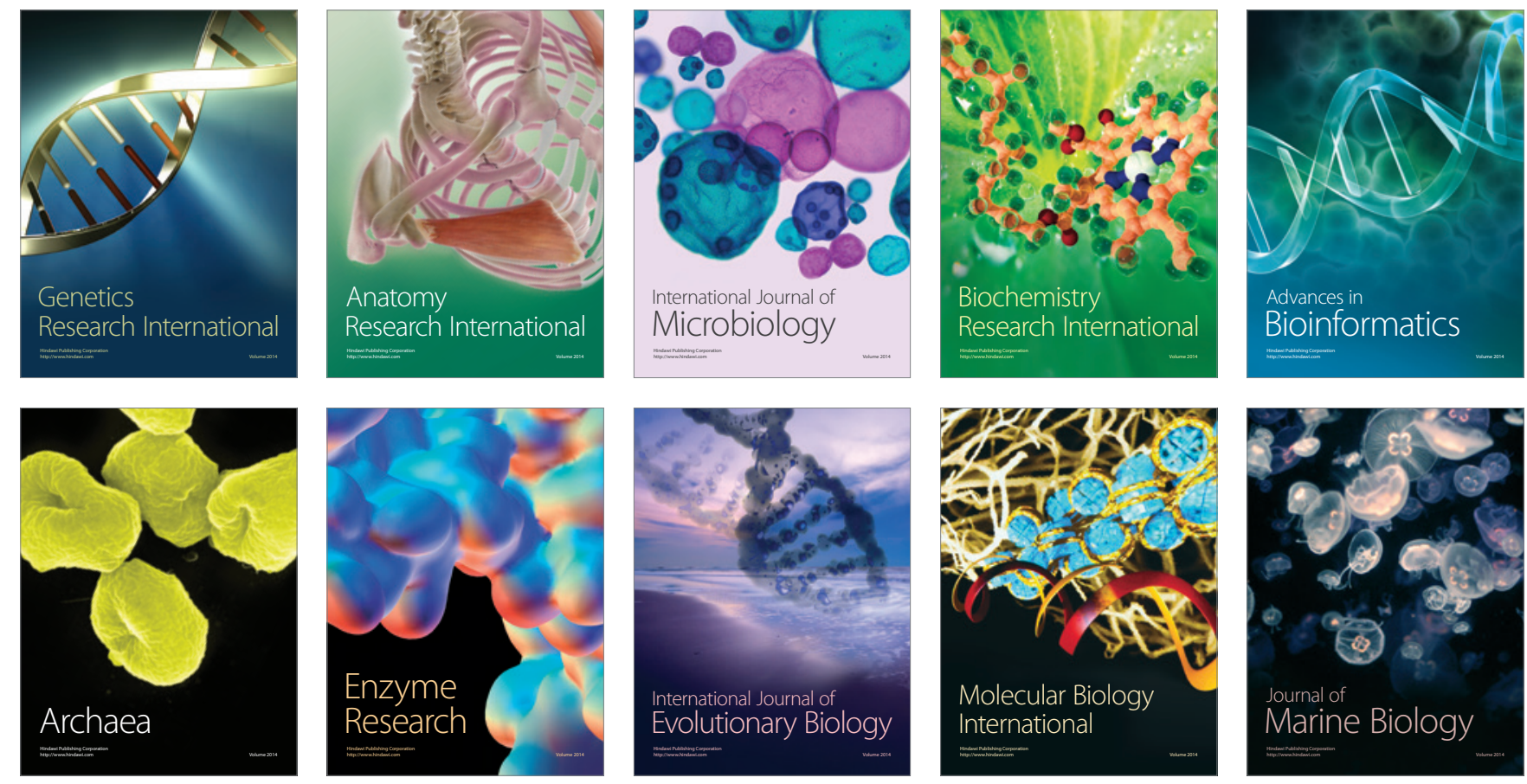